\title{
Plasmid Mediated Antibiotic Resistance in Isolated Bacteria From Burned Patients
}

\author{
Fahimeh Beige ${ }^{1,{ }^{*}}$; Majid Baseri Salehi ${ }^{1}$; Nima Bahador ${ }^{1}$; Sina Mobasherzadeh ${ }^{2}$ \\ ${ }_{1}^{1}$ Department of Microbiology, Sciences and Research Branch, Islamic Azad University, Fars, IR Iran \\ ${ }^{2}$ Nosocomial Infection Research Center, Isfahan University of Medical Sciences, Isfahan, IR Iran \\ *Corresponding author: Fahimeh Beige, Department of Microbiology, Sciences and Research Branch, Islamic Azad University, Fars, IR Iran. Tel:+98-9133152753, E-mail: beigi.fahimeh@ \\ yahoo.com \\ Received: July 13, 2013; Revised: March 29, 2014; Accepted: April 9, 2014
}

\begin{abstract}
Background: Nowadays, the treatment of burned patients is difficult because of the high frequency of infection with antibiotic resistance bacteria.

Objectives: This study was conducted to evaluate the level of antibiotic resistance in Gram-negative bacteria and its relation with the existence of plasmid.

Materials and Methods: The samples were collected from two hundred twenty hospitalized burned patients in Isfahan burn hospital during a three-month period (March 2012 to June 2012). The samples were isolated and the Gram-negative bacteria were identified using phenotypic method and API 20E System. Antibiotic susceptibility and plasmid profile were determined by standard Agar disc diffusion and plasmid spin column extraction methods.

Results: Totally 117 Gram-negative bacteria were isolated, the most common were Pseudomonas aerugionsa (37.6\%), P. fluorescens (25.6\%), Acinetobacter baumanii (20/5\%) and Klebsiella pneumoniae (7.6\%), respectively. The isolates showed high frequency of antibiotic resistance against ceftazidime and co-amoxiclave (100\%) and low frequency of antibiotic resistance against amikacin with (70\%).The results indicated that $60 \%$ of the isolates harboured plasmid. On the other hand, the patients infected with A. baumanii and P. aeruginosa were cured (with $60 \%$ frequency) whereas, those infected with $P$. fluorescens were not cured. Hence, probably antibiotic resistance markers of $A$. baumanii and $P$. aeruginos $a$ are plasmid mediated; however, $P$. fluorescens is chromosomally mediated.

Conclusions: Based on our findings, $P$. aerugionsa is a major causative agent of wound infections and amikacin could be considered as a more effective antibiotic for treatment of the burned patients.

Keywords:Plasmid; Infection; Patients
\end{abstract}

\section{Background}

Bacterial infection in burned patients is a major problem for health care settings because of the increasing level of mortality and hospitals cost (1). Gram-negative bacteria including Pseudomonas aeruginosa, Acinetobacter baumanii andKlebsiella pneumoniae are the most frequent pathogens isolated from burned infected wounds (2-4). In 2008, the antibacterial resistance pattern of aerobic bacteria isolated from burn patients showed that ceftazidime and cefotaxime resistant Pseudomona spp. is a common etiological agent of infections (5). In 2010, $A$. baumanii isolated from burned patients contained carbapenemase genes in their genome (6). Generally, many mechanisms are responsible for antibiotic resistance in Gram-negative bacteria. Relatively, mobile gene elements such as transposon, integrons and plasmids, play important roles in antibiotic resistance character (7-9).

\section{Objectives}

The present study was conducted to evaluate the antibiotic resistance patterns and its relation with the exis- tence of plasmid in Gram-negative bacteria isolated from burned patients in Isfahan burned hospital, Iran.

\section{Materials and Methods}

\subsection{Bacterial Strains}

A total of 139 non-duplicate bacterial isolates were collected from two hundred twenty patients from March to June 2012. Samples were taken at the beginning of the first bondage during the hospital stay (10). The phenotypic features of isolates were identified by standard biochemical tests such as Gram staining, sugar fermentation and API 20E system (Biomerix Co, France).

\subsection{Determination of Antibiotic Susceptibility of the Isolates by Disc Diffusion Method}

Determination of antibiotic susceptibility patterns were carried out by the disc diffusion method according to CLSI guidelines (11). To perform the test, antago-

Copyright (C) 2015, Ahvaz Jundishapur University of Medical Sciences. This is an open-access article distributed under the terms of the Creative Commons Attribution-NonCommercial 4.0 International License (http://creativecommons.org/licenses/by-nc/4.0/) which permits copy and redistribute the material just in noncommercial usages, provided the original work is properly cited. 
Beige F et al.

nistic bacteria viz., Escherichia coli ATCC 25922, P. aeruginosa ATCC 27853, Staphylococcus aureus ATCC 25923 and Enterococcus faecalis ATCC 29212 cultured in nutrient broth and their turbidity were adjusted to $0.5 \mathrm{Mc}$ Farland standard. The suspensions were streaked onto Mueller-Hinton agar plates and the following antibiotic disks (Hi-Media, India) amikacin (30 $\mu \mathrm{g})$, cefotaxim (30 $\mu \mathrm{g})$, ciprofloxacin $(5 \mu \mathrm{g})$, imipenem $(10 \mu \mathrm{g})$, meropenem $(5 \mu \mathrm{g})$, co-trimoxazole $(25 \mu \mathrm{g})$, piperacillin/tazobactam $(25 \mu \mathrm{g})$, ceftriaxone $(30 \mu \mathrm{g})$, amoxicillin-clavulanic acid $(30 \mu \mathrm{g})$, ceftazidime $(30 \mu \mathrm{g})$ were placed on the seeded media. The plates were incubated at $37^{\circ} \mathrm{C}$ for $18-24$ hours and then the inhibition zone around each antibiotic disk was measured and recorded.

\subsection{Plasmid Isolation}

Plasmid was isolated using standard method (Vivantis nucleic acid extraction kit, GF-1 model, version 2.2, Germany) recommended by Birnboim et al. (12) and the purity of plasmid was evaluated at $260 \mathrm{~nm}$ by spectrophotometer (Eppendorf Biophotometer 6131, Germany). The plasmid DNA was observed by gel electrophoresis. To prepare the gel, Agarose gel powder (2\%) was dissolved in TAE buffer (40 Mm Tris-Hcl, $50 \mathrm{mM}$ Sodium acetate, $1 \mathrm{Mm}$ EDTA; $\mathrm{pH}$ 8). The extracted DNA was added to the gel and the Gel was run for two and half hours at $50 \mathrm{~V}$, stained for 30 min with ethidium bromide $(0.5 \mu \mathrm{g} / \mathrm{mL})$. The plasmids were visualized under UV light in Alpha imager gel documentation system (Syngene, UK) (Table 1).

\subsection{Plasmid Curing}

The isolates were showing resistance character (100\%) subjected to plasmid curing. Ethidium bromide was serially diluted in Muller Hinton broth. The curing agent was tested at 500, 250, 125, 62.5, $31.2 \mu \mathrm{g} / \mathrm{mL}$ concentrations. Overnight growth culture of five isolates subjected to plasmid curing and each of them inoculated into the tube containing $1 \mathrm{~mL}$ Muller Hinton broth and the incubated at $44^{\circ} \mathrm{C}$ for 24 hours. The minimal inhibitory concentration (MIC) of Ethidium bromide was determined then the highest concentration permitting growth (SIC) was considered as plasmid curing. The overnight culture was inoculated on Mac Conkey agar with sic of curing agents and incubated at $37^{\circ} \mathrm{C}$ for two days. The single colonies were picked up by sterile toothpicks and inoculated on nutrient agar plate (30 colonies/plate).The plates was incubated at $37^{\circ} \mathrm{C}$ for 24 hours and used as master plates. These colonies were inoculated on nutrient agar with ciprofloxacin $(5 \mu \mathrm{g})$ and on nutrient agar with meropenem $(5 \mu \mathrm{g})$ and on nutrient agar with ceftriaxone (30 $\mu \mathrm{g})$ and then incubated at $37^{\circ} \mathrm{C}$ for 48 hours. The colonies that did not grow on selective medium, were known as cured colonies. At the same time, a non-cured culture on selective medium as a control for curing of each marker was performed. The loss of plasmid DNA was confirmed by gel electrophoresis.
Figure 1. Antibiotic Resistance of the Isolates

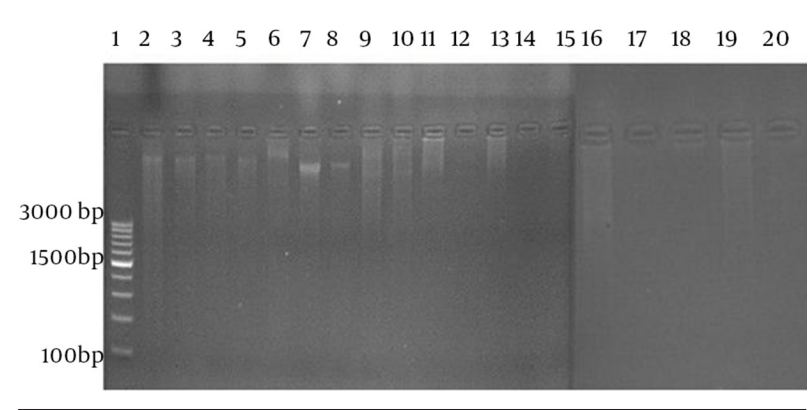

AN, Amikacin; AMC, Ampicillin-clavulanic acid; CIP, Ciprofloxacin; CTX Cefotaxime; CTR, Ceftriaxone, IMP, Imipeneme; MEM, Meropenem; COT, Co-trimaxazole; T2P, piracillin/Tazobactam; CAZ, Ceftazidime.

Figure 2. Plasmis Profile of Isolates

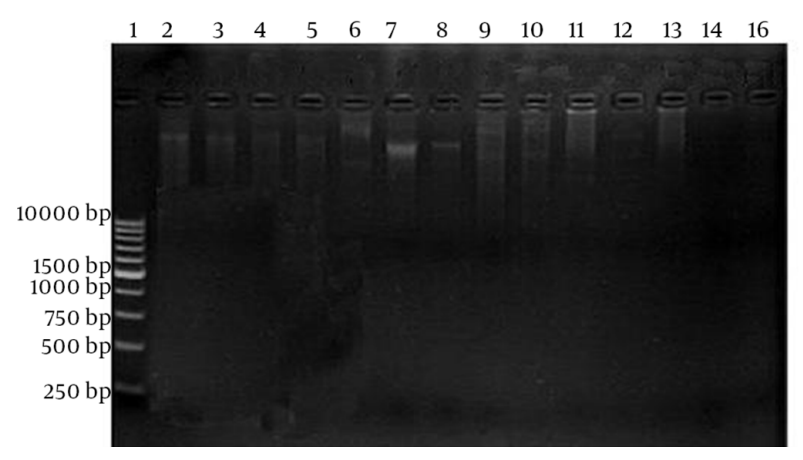

Line 1, Smart marker (100-3000bp); Line 2 to 5, A. baumanii; Line 6 and 7, $P$. aeruginosa; Line 8 and 9, K. pnoumoniae harbored two plasmid bands; Line 18,19 and 20: P. fluorescens.

\section{Results}

\subsection{Identification and Antibiotic Susceptibility of the Isolates}

Totally 117 Gram-negative bacteria were isolated and the most common were $P$. aerugionsa (37.6\%), P. fluorescens (25.6\%), A. baumanii (20.5\%) and K. pneumoniae (7.6\%), respectively. The isolates were resistant against ceftazidime and co-amoxiclave with high frequency (100\%) and against amikacin with low frequency (70\%) (Figure 1).

\subsection{Plasmid Isolation}

Nineteen resistant strains against all antibiotics were subjected for plasmid isolation (Figure 2).

\subsection{Plasmid Curing}

Five isolates of bacteria that showing resistance to all antibiotics were selected for plasmid curing. The results showed that A. baumanii and P. aeruginosa were cured (with $60 \%$ frequency) whereas; P. fluorescens was not cured (60\%). 
Table 1. Susceptibility of the Bacterial Strains to Ethidium Bromide

\begin{tabular}{lcc}
\hline Bacteria of Isolates & SIC, $\mu$ g/mL & MIC, $\mu$ g/mL \\
\hline A. baumanii & 62.5 & 125 \\
A. baumanii & 250 & 500 \\
P. flourescens & 1000 & 2000 \\
P. aeruginosa & 1000 & 2000 \\
A. baumanii & 125 & 250 \\
\hline
\end{tabular}

Table 2. Sensivity of Cured Strains to the Marked Antibiotics With Ethidium Bromide

\begin{tabular}{lc}
\hline Antibiotics & Susceptibility of Cured Strains, \% \\
\hline Ceftriaxone & 66 \\
Meropenem & 33 \\
Ciprofloxacin & 83 \\
\hline
\end{tabular}

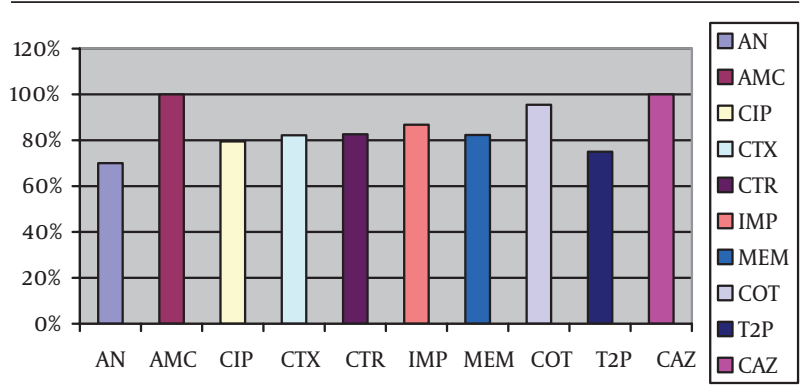

Figure 3. Verification of the Existence of Plasmid in Cured Strains of P. aeruginosa and $A$. baumanii

\subsection{Determination of Plasmid Mediated Antibiotic Resistance}

Our findings showed that $83 \%$ to $66 \%$ of the cured strains were sensitive to ciprofloxacin and ceftriaxone. However, $33 \%$ of the isolates were sensitive to meropenem (Table 2 and Figure 3 ).

\section{Discussion}

Recently, high frequency antibiotic resistance bacteria, especially in the hospitals, culminated a serious problem for treatment of infectious diseases. In this regards, several resistant strains of S. aureus, K. pneumonia and $P$. aeruginosa strains against ceftazidime and imipenem and carbapenem respectively were isolated from hospitals $(3,13)$. Parallel to these reports the present study isolated antibiotic resistant Gram-negative bacteria from burned patient in hospitals. Some of the isolates showed resistance to ceftazidime and Amoxicillin-clavunic acid. In a similar study P. seudomonas aeruginosa isolated from burned patient in Sanandaj, Iran were 100\% resistant to ceftazidime (14). On the other hand, parallel to our finding several reports showed that amikacin has effective antibiotic featuers against burned infectious agents (15-17)

In the present study, the most common Gram-negative bacteria isolated from the patients were P. aeruginosa, Acinetobacter spp and K. pneumoniae. Out of all, Acinetobacter spp and $P$. aeruginosa isolates exhibited common antibiotic resistance pattern $(3,18,19)$. In different investigation in Brasilia P. aeruginosa, A. baumanii and K. pneumoniae were introduced as collective nosocomial infectious agents (20). Generally, antibiotic resistance markers located in the chromosomes, plasmids, integron and transposons (21). Of all, antibiotic resistance markers encoded in plasmid play an important role for transferring the resistance marker among different bacteria $(22,23)$. In the present study $60 \%$ of the strains harbored plasmid and they showed resistance property to ciprofloxacin and ceftriaxone.

In 2003,95\% of antibiotic resistant $P$. aeruginos $a$ isolated from burn patients in Tehran hospitals harbored plasmid (24). In addition, plasmid curing confirmed the relationship between antibiotics resistance character and the existence of plasmid (25). In the present study cured $A$. baumanii and $P$. aeruginosa lost their resistance markers after losing their plasmids. Therefore, it can be interpreted that probably antibiotic resistance markers of these bacteria are plasmid mediated. Overall, our investigation showed the existence of the resistance markers in the plasmid of isolated bacteria from burned patients. Hence these markers might easily transfer among the bacteria in the hospitals.

\section{Acknowledgements}

The authors would like to thank Dr. Soroshnia, Mr. Radan, Mr. Kardi and the laboratory personnel of ImamMosa-Kazem Hospital for their brilliant assistance.

\section{References}

1. Wenzel RP. The Lowbury Lecture. The economics of nosocomial infections. J Hosp Infect. 1995;31(2):79-87.

2. Elwell LP, Inamine JM, Minshew BH. Common plasmid specifying tobramycin resistance found in two enteric bacteria isolated from burn patients. Antimicrob Agents Chemother. 1978;13(2):312-7.

3. Song W, Lee KM, Kang HJ, Shin DH, Kim DK. Microbiologic aspects of predominant bacteria isolated from the burn patients in Korea. Burns. 2001;27(2):136-9.

4. Heritier C, Poirel L, Lambert T, Nordmann P. Contribution of acquired carbapenem-hydrolyzing oxacillinases to carbapenem resistance in Acinetobacter baumannii. Antimicrob Agents Chemother. 2005;49(8):3198-202.

5. Rajput A, Singh KP, Kumar V, Sexena R, Singh RK. Antibacterial resistance pattern of aerobic bacteria isolates from burn patients in tertiary care hospital. Biomed Res. 2008;19(1).

6. Bogaerts P, Naas T, El Garch F, Cuzon G, Deplano A, Delaire T, et al. GES extended-spectrum beta-lactamases in Acinetobacter baumannii isolates in Belgium. Antimicrob Agents Chemother. 2010;54(11):4872-8.

7. Ombui JN, Kimotho AM, Nduhiu JG. Antimicrobial resistance patterns and plasmid profiles of Staphylococcus aureus isolated from milk and meat. East Afr Med J. 2000;77(9):463-7.

8. Watanabe T, Fukasawa T. Episome-mediated transfer of drug resistance in Enterobacteriaceae. II. Elimination of resistance factors with acridine dyes. J Bacteriol. 1961;81:679-83. 
9. Spengler G, Molnar A, Schelz Z, Amaral L, Sharples D, Molnar J. The mechanism of plasmid curing in bacteria. Curr Drug Targets. 2006;7(7):823-41

10. Forbes BA, Sahm DF, Weissfeld AS. Bailey and Scott's Diagnostic Microbiology.Mosby: Elsevier; 2002.

11. Bauer AW, Kirby WM, Sherris JC, Turck M. Antibiotic susceptibility testing by a standardized single disk method. Am J Clin Pathol. 1966;45(4):493-6.

12. Birnboim HC, Doly J. A rapid alkaline extraction procedure for screening recombinant plasmid DNA. Nucleic Acids Res. 1979;7(6):1513-23.

13. Boyce JM, White RL, Causey WA, Lockwood WR. Burn units as a source of methicillin-resistant Staphylococcus aureus infections. JAMA. 1983;249(20):2803-7.

14. Kohanteb J, Dayaghi M, Motazedian M, Ghayumi MA. Comparison of biotyping and antibiotyping of Pseudomonas aeruginosa isolated from patients with burn wound infection and nosocomial pneumonia in Shiraz, Iran. PakJ Biol Sci. 2007;10(11):1817-22.

15. Revathi G, Puri J, Jain BK. Bacteriology of burns. Burns. 1998; 24(4):347-9.

16. Estahbanati HK, Kashani PP, Ghanaatpisheh F. Frequency of Pseudomonas aeruginosa serotypes in burn wound infections and their resistance to antibiotics. Burns. 2002;28(4):340-8.

17. Signorini M, Grappolini S, Magliano E, Donati L. Updated evalu- ation of the activity of antibiotics in a burn centre. Burns. 1992;18(6):500-3.

18. Nasser S, Mabrouk A, Maher A. Colonization of burn wounds in Ain Shams University Burn Unit. Burns. 2003;29(3):229-33.

19. Towner KJ. Acinetobacter: an old friend, but a new enemy. J Hosp Infect. 2009;73(4):355-63.

20. Mendes C, Oplustil C, Sakagami E, Turner P, Kiffer C, Mystic Brazil Group. Antimicrobial susceptibility in intensive care units: MYSTIC Program Brazil 2002. Braz J Infect Dis. 2005;9(1):44-51.

21. Courvalin P. Transfer of antibiotic resistance genes between gram-positive and gram-negative bacteria. Antimicrob Agents Chemother. 1994;38(7):1447-51.

22. Brown TA. Plasmids. In: Talebatabaei Yazdi M, Sepehrizzadeh Z editors. Textbooks of Gene Cloning \& DNA analysis. 6th ed; 2010. pp. 33-9.

23. Amabile-Cuevas CF, Chicurel ME. Bacterial plasmids and gene flux. Cell.1992;70(2):189-99.

24. Shahcheraghi F, Feizabadi MM, Yamin V, Abiri R, Abedian Z. Serovar determination, drug resistance patterns and plasmid profiles of Pseudomonas aeruginosa isolated from burn patients at two hospitals of Tehran (IRAN). Burns. 2003;29(6):547-51.

25. Baserisalehi M, Bahador N. A Study on Relationship of Plasmid with Antibiotic Resistance in Thermophilic Campylobacter spp. Isolates from Environmental Samples. Biotechnol J. 2008;7(4):813-7. 